\title{
High-frequency monitoring of stream water physicochemistry on sub-Antarctic Marion Island
}

\author{
M-J Stowe ${ }^{1 *}$, DW Hedding ${ }^{2}$, FD Eckardt ${ }^{1}$ and W $\mathrm{Nel}^{3}$ \\ 'Department of Environmental and Geographical Science, University of Cape Town, Private Bag X3, Rondebosch, 7701, South Africa \\ ${ }^{2}$ Department of Geography, University of South Africa, Florida, 1710, South Africa \\ ${ }^{3}$ Department of Geography and Environmental Science, University of Fort Hare, Private Bag X1314, Alice, 5700, South Africa
}

\begin{abstract}
Given the remoteness and challenging environmental conditions on sub-Antarctic Marion Island, continuous high-resolution studies of the island's natural water systems are rare. Subsequently, current understanding of the island's hydrochemistry is based entirely on manual point-based measurements. To address this research gap we analysed continuous, in-situ highfrequency physicochemical measurements ( $\mathrm{pH}$, water temperature, dissolved oxygen (DO), and electrical conductivity (EC)) from the Soft Plume River over the period 21 April 2015-26 April 2015. We observed a sharp, short-term response from all measurements to a precipitation event that was superimposed on consistent but subtle diel (i.e. $24 \mathrm{~h}$ ) cycles throughout the study. Total variation in $\mathrm{pH}$ and electrical conductivity amounted to 1.3 units and $27.7 \mu \mathrm{S} / \mathrm{cm}$ respectively. Stream water temperature was less variable $\left(6.2^{\circ} \mathrm{C}\right)$ than air surface temperature $\left(14.2^{\circ} \mathrm{C}\right)$. Total variation in DO was $2.0 \mathrm{mg} / \mathrm{L}$. Aside from the precipitation-induced response, diel oscillations were small and only visible through the use of continuous, highresolution monitoring. Findings highlight the advantages of continuous high-frequency monitoring in capturing the range of daily variation and elucidating diel cycles in stream water physicochemistry on sub-Antarctic Marion Island that have not previously been accounted for.
\end{abstract}

Keywords: diurnal, diel cycles, in situ, Marion Island, sub-Antarctic

\section{INTRODUCTION}

Diel (i.e. $24 \mathrm{~h}$ ) oscillations in stream water can result from differing physical, biological, or chemical processes that operate on a day-night cycle (Nimick et al., 2011). Study of diel cycles can help reveal which biogeochemical processes occur relatively rapidly in natural waters and therefore which processes play an integral role in the normal functioning of natural water systems (Neal et al., 2012). On isolated maritime islands, hydrological systems often exhibit a strong coupling with local and synoptic climatic phenomena that regulate various hydroand bio-geochemical processes (Tomlinson and De Carlo, 2003; Contador et al., 2015). As a result, the physicochemistry of stream water often responds quickly to even small changes in climate. Physical and chemical parameter values in stream water vary widely over multiple of scales in space and time and therefore, discontinuous sampling does not capture the full range of values. To better understand the processes which link catchment hydrochemistry and ecosystem functioning on oceanic islands, measurement frequencies should be able to capture the catchment's hydrological response, which in these environments is often in the order of minutes or hours (Grobbelaar et al., 1987; Scholfield et al., 2005; Moraetis et al., 2010; Raposeiro et al., 2011; Halliday et al., 2012). Such an understanding is possible through the use of continuous, in-situ high-resolution monitoring (Kirchner et al., 2004; Rode et al., 2016).

The remoteness of sub-Antarctic Marion Island, as part of the Prince Edward Islands (PEI) in the Indian Sector of the Southern Ocean, along with extreme weather conditions,

* To whom all correspondence should be addressed e-mail: michaeljamesy@gmail.com Received 2 August 2017; accepted in revised form 3 April 2018 makes continuous, high-resolution data collection difficult (Fig. 1a; Wade et al., 2012). In addition, in-situ high-frequency monitoring is associated with various challenges, such as frequent instrument maintenance and calibration, and data management issues that are intensified in isolated, maritime environments (Strobl and Robillard, 2008). On Marion Island, data collection typically involves a single field campaign within a year, with research assistants stationed on the island responsible for sampling and monitoring programmes that are designed to operate throughout the year.

To date, no continuous in-situ measurements have ever been made of physical and/or chemical characteristics of stream water on Marion Island. As a result, understanding of the island's stream physicochemical dynamics is based entirely on manual, often randomly taken, point-based measurements that have been made concomitantly with water sample collection (Grobbelaar, 1974, 1975, 1978a, 1978b, 1978c; Van Staden, 2011; Dartnall and Smith, 2012).

While these low-frequency data provide necessary information on the mean chemical state of the streams (Burt et al., 2011), the measurements mask sub-daily variability and are often prone to high uncertainties associated with underrepresentation of high-discharge and short-duration events that may result in significant changes in stream dynamics (Jordan and Cassidy, 2011; Wilby et al., 2014; Sherson et al., 2015).

Although many studies have reported extended periods of in-situ monitoring of various physicochemical determinants in remote and challenging environments, such as the McMurdo Dry Valleys, Antarctica (McKnight et al., 2015; Wlostowski et al., 2016), these data are particularly rare for isolated maritime islands in the Southern Hemisphere. To address this research gap, we describe new insights into stream water hydrochemical dynamics on Marion Island based on analysis of high-frequency physicochemical measurements $(\mathrm{pH}$, 
water temperature, dissolved oxygen (DO), and electrical conductivity (EC)). With these data, we investigate variability in stream water physicochemistry over a 6-day field campaign in April 2015. We highlight the advantages of continuous in-situ monitoring versus manual point-based measurements, which have up to now been used to characterise the island's stream water chemical dynamics.

\section{MATERIALS AND METHODS}

\section{Study area}

Marion Island ( $46^{\circ} 54^{\prime} \mathrm{S}$ and $\left.37^{\circ} 51^{\prime} \mathrm{E}\right)$ is the larger of two islands that comprise the PEI group (Fig. 1a). The island, situated in the Indian sector of the Southern Ocean, consists of a peak of a shield volcano. The island has an area of $\pm 293 \mathrm{~km}^{2}$ and with its highest point (Mascarin peak) at $1240 \mathrm{~m}$ amsl (Hedding, 2008). The island's climate is strongly influenced by its hyperoceanic position within the westerly wind belt (Rouault et al., 2005). The island experiences high precipitation amounts
( $\sim 234 \mathrm{~mm} / \mathrm{yr}$ ) evenly distributed over the annual cycle. The surrounding Southern Ocean moderates diurnal and annual temperature variations (Pendlebury and Barnes-Keoghan, 2007). Mean maximum and minimum temperatures at the research station are 10.5 and $5.0^{\circ} \mathrm{C}$, whereas mean values in winter are 6.0 and $1.0^{\circ} \mathrm{C}$, respectively. Mean daily temperature ranges are on average less than $2^{\circ} \mathrm{C}$ and $3^{\circ} \mathrm{C}$ in winter and summer, respectively (Boelhouwers et al., 2003). Combined with these conditions are high relative humidity, cloud-cover and strong westerly to north-westerly winds (Le Roux, 2008).

\section{Study site}

Perennial streams are uncommon on the island as porous lavas dominate much of the island's topography so precipitation infiltrates the surface (Boelhouwers et al., 2008). Streams are generally oligotrophic with low rates of primary productivity and biological activity (Cooper et al., 1992). The Soft Plume River (SPR) is the only perennial stream on the island. The SPR is located on the south-eastern quadrant of the island and flows

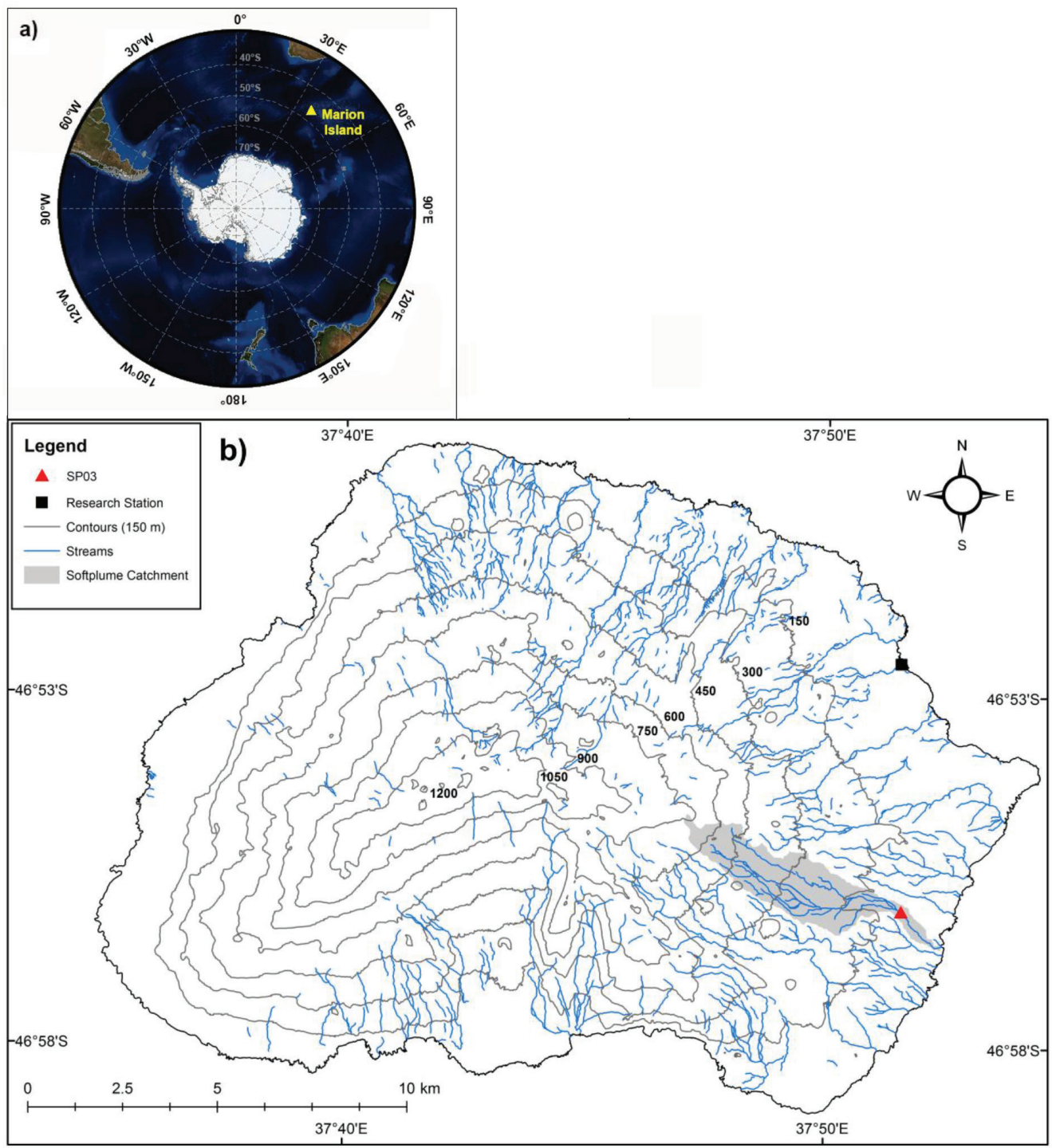

Figure 1

a) Location of Marion Island in relation to other major landmasses, b) Map of Marion Island indicating the study site (SP03; 105 m amsl) along the Soft Plume River (SPR) and the research station ( 24m amsl). All streams are included for reference. 
through one of the larger catchments of the island (Fig. 1b; $\sim 5.26 \mathrm{~km}^{2}$ ). The upper reaches of the SPR are shallow with some portions interrupted by lava flows. The banks of the SPR consist mainly of peat and are usually steep in the lower reaches owing to fluvial erosion. Fringe vegetation consists predominantly of the alien grass, Poа апnиa, which often grows submerged together with filamentous algae. Other fringe vegetation includes Agrotis megellanica, Juncus Scheuchzeriodes, Ranunculus biternatus and the moss Drepanocladus uncinatus, which colonise the edge of various sections of the stream (Grobbelaar, 1974). Our study site (SP03) is situated at $\sim 103 \mathrm{~m}$ amsl and is downstream of the confluence of all major tributaries (Fig. 1b).

\section{Data collection}

A Eureka Manta multiprobe (Eureka Environmental Engineering, Austin, TX, USA) was set up at SP03 (Fig. 1b). The multiprobe continuously logged the following physicochemical parameters in situ at 5-min intervals; $\mathrm{pH}$, water temperature $\left({ }^{\circ} \mathrm{C}\right), \mathrm{DO}(\mathrm{mg} / \mathrm{L})$ and EC $(\mu \mathrm{S} / \mathrm{cm})$. These parameters had accuracies of \pm 0.2 units, $\pm 0.08^{\circ} \mathrm{C}, \pm 0.6 \mathrm{mg} / \mathrm{L}$ and $\pm 0.5 \%$ of reading, respectively. These data were converted to hourly averages to generate a new data set. All probes were calibrated in water-saturated air prior to deployment in the field. Data were downloaded manually in the field on 26 April 2015. Hourly temperature $\left({ }^{\circ} \mathrm{C}\right)$ and rainfall amount $(\mathrm{mm})$ data, recorded at the research station ( $24 \mathrm{~m}$ amsl) on Marion Island (Fig. 1b), were obtained from the South African Weather Service (SAWS). Descriptive statistics were determined for all physicochemical data (Table 1). All data were collated, analysed and plotted using R statistical software (version 3.3.0; R Core Team, 2016).

\section{RESULTS}

Summary statistics of mean daily stream physicochemical values are presented in Table 1 . A time series of stream $\mathrm{pH}$, water temperature, DO and EC recorded at SP03, as well as air surface temperature and rainfall amount measured at the research station, are shown in Fig. 2a-f. On 22 April 2015, a very strong cold front from a deep mid-latitudinal cyclone with its centre just over the Antarctic coastline moved over the island from west to east which brought with it $13 \mathrm{~mm}$ of precipitation between 15:00 and 21:00 (GMT+3). During this period air surface temperature decreased from $9.2^{\circ} \mathrm{C}$ to $2^{\circ} \mathrm{C}$. This synoptic event triggered rapid and significant changes in the recorded physicochemistry of the SPR (see Fig. 2a-f). $\mathrm{pH}$ decreased from 7.4 to 6.4 , stream water temperature dropped from 7.5 to $4.6^{\circ} \mathrm{C}$ and EC dropped from 64.7 to $38.3 \mu \mathrm{S} / \mathrm{cm}$ between 15:00 and 21:00. Conversely, DO increased from 11.5 to $12.5 \mathrm{mg} / \mathrm{L}$ over the same time period. These changes represented the fastest rates of change over the study period.

These changes in response to the precipitation event were superimposed on diel cycles of physicochemical measurements. Over the time series mean $\mathrm{pH}$ was 7.2 and ranged from 6.3 to 7.5 units. pH increased throughout the day and flattened-off during the night. Maxima were typically reached between 13:00 and 15:00 (GMT+3), followed by a decrease and minima during night-time hours.

Stream water temperature had a mean of $5.9^{\circ} \mathrm{C}$, and ranged from $3.3^{\circ} \mathrm{C}$ to $9.9^{\circ} \mathrm{C}$. Air surface temperature measured at the research station was $8.2^{\circ} \mathrm{C}$, with a range from $2.0^{\circ} \mathrm{C}$ to $16.2^{\circ} \mathrm{C}$. Stream water temperature increased throughout the day with maxima in the afternoon, followed by a decrease and minima during night-time hours. Stream water temperature minima and maxima occurred between 00:00-04:00 and 15:00-18:00 (GMT+3), respectively. Stream water temperature displayed a significant, positive linear trend between 21 April 2015 and 26 April $2015\left(r^{2}=0.39 ; p<0.0001\right)$. Stream pH maximum precedes stream water temperature maximum. A cross-correlation function identified dominant and significant positive cross correlations at lags of 2-3 hours, as illustrated in Fig. 2a,b.

DO had a mean concentration of $12.1 \mathrm{mg} / \mathrm{L}$ with a range from $11.0 \mathrm{mg} / \mathrm{L}$ to $13.00 \mathrm{mg} / \mathrm{L}$. There was a significant negative correlation between stream water temperature and DO concentrations $(r=-0.96, p<0.0001)$. DO concentrations begin to decrease during the morning as stream water is warmed and oxygen solubility decreases. Following water temperature oscillations, diel DO cycles generally exhibited night-time maxima and daytime minima. A weak significant, negative linear trend was identified for DO concentrations over the period 21 April 2015-26 April $2015\left(r^{2}=0.28 ; p<0.0001\right)$.

Mean EC was $61.7 \mu \mathrm{S} / \mathrm{cm}$ and ranged from 38.8 to $66.5 \mu \mathrm{S} / \mathrm{cm}$. After the precipitation-induced response, EC tended to increase throughout the day and reach maximum concentration during night-time hours between 18:00 and 22:00 GMT+3. Minimum EC concentrations were typically reached during the day between 10:00 and 15:00 GMT+3.

\section{DISCUSSION}

Mean physicochemical parameter values measured in the SPR reflected the island's undisturbed environment, prevailing climatic conditions and relatively low rates of primary

TABLE 1

Daily (00:00-24:00 GMT+3) mean values \pm standard deviation $(1 \sigma)(\mathrm{max}-\mathrm{min})$ of physicochemical values determined from hourly measurements at SP03 between 21 April 2015 - 26 April 2015. N; number of hourly measurements, DO; dissolved oxygen, EC; electrical conductivity.

\begin{tabular}{|l|c|c|c|c|c|}
\hline Date & $\boldsymbol{N}$ & $\mathrm{pH}$ & Water Temperature $\left({ }^{\circ} \mathrm{C}\right)$ & $\mathrm{DO}(\mathrm{mg} / \mathrm{L})$ & $\mathrm{EC}(\mu \mathrm{S} / \mathrm{cm})$ \\
\hline 21 April 2015 & 8 & $7.3 \pm 0.11(0.2)$ & $4.7 \pm 0.50(1.2)$ & $12.3 \pm 0.10(0.2)$ & $65.8 \pm 0.71(2.0)$ \\
\hline 22 April 2015 & 24 & $7.1 \pm 0.39(1.2)$ & $5.7 \pm 1.26(3.8)$ & $12.1 \pm 0.42(1.5)$ & $58.6 \pm 9.88(26.5)$ \\
\hline 23 April 2015 & 24 & $7.1 \pm 0.22(0.8)$ & $4.1 \pm 0.76(2.0)$ & $12.7 \pm 0.24(0.7)$ & $58.2 \pm 5.04(16.7)$ \\
\hline 24 April 2015 & 24 & $7.2 \pm 0.10(0.3)$ & $5.8 \pm 1.35(3.6)$ & $12.2 \pm 0.37(1.0)$ & $63.5 \pm 0.89(2.8)$ \\
\hline 25 April 2015 & 24 & $7.3 \pm 0.11(0.4)$ & $7.7 \pm 1.31(3.7)$ & $11.6 \pm 0.35(1.0)$ & $63.8 \pm 1.10(3.6)$ \\
\hline 26 April 2015 & 16 & $7.3 \pm 0.13(0.3)$ & $7.2 \pm 0.76(2.3)$ & $11.8 \pm 0.18(0.6)$ & $63.6 \pm 0.61(1.9)$ \\
\hline
\end{tabular}




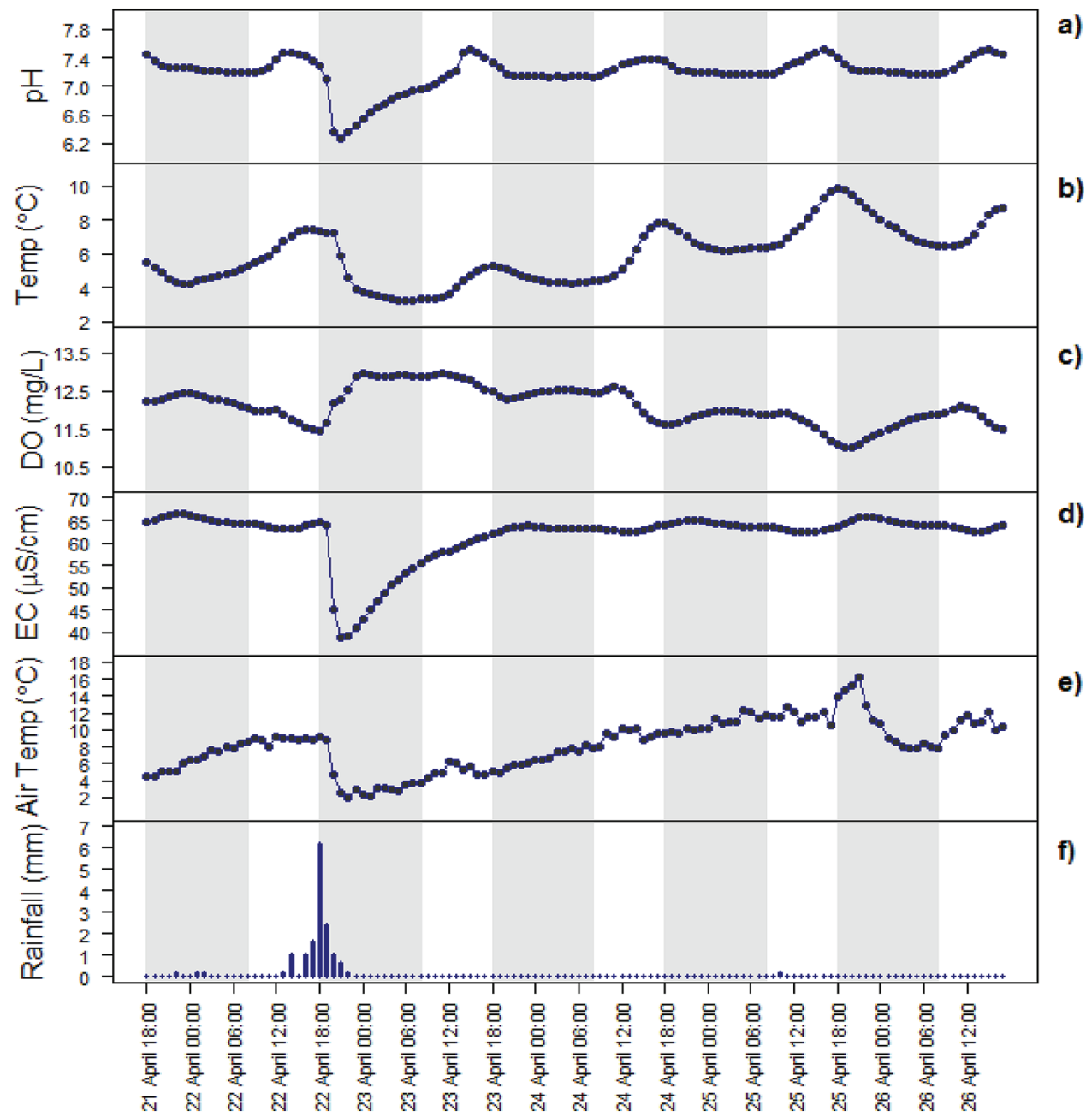

Figure 2

Time series of hourly measurements of a) $\mathrm{pH}, b$ ) stream water temperature $\left({ }^{\circ} \mathrm{C}\right)$, c) dissolved oxygen $(\mathrm{DO} ; \mathrm{mg} / \mathrm{L})$ and d) electrical conductivity (EC; $\mu \mathrm{S} /$ $\mathrm{Cm}$ ) in the Soft Plume River at SP03 from 21 April 2015 to 26 April 2015. Hourly recordings of e) air surface temperature $\left({ }^{\circ} \mathrm{C}\right)$, and f rainfall amount (mm) were made at the research station. Grey bars indicate approximate night-time hours (18:00-08:00 GMT+3).

productivity and bacterial activity in stream water. Mean stream water $\mathrm{pH}$ was neutral (7.2) and was consistent with previous point-based measurements made by Grobbelaar (1974; 6.8), Van Staden $(2011 ; 6.9)$ and Dartnall and Smith (2012; 6.8) (Table 2). EC of stream water is a sum-parameter for the concentration of dissolved ions. Mean EC concentration in the SPR $(61.7 \mu \mathrm{S} / \mathrm{cm})$ is consistent with the aforementioned studies (Table 2) and supports findings of low solute concentrations in stream water on the island (Grobbelaar, 1975). Taken, these high frequency $\mathrm{pH}$ and $\mathrm{EC}$ data from the SPR effectively capture the range of values determined by previous point-based measurements, despite only representing data from a single stream and a limited period of annual hydroclimatic variability.

Water temperature and DO have previously not been measured in stream water on the island. Average stream water temperature $\left(5.9^{\circ} \mathrm{C}\right)$ was only slightly below mean air surface temperature measured at the research station $\left(8.2^{\circ} \mathrm{C}\right)$, and reflected the island's temperature regime which is moderated by the surrounding Southern Ocean (Le Roux, 2008). Mean DO in the SPR $(12.1 \mathrm{mg} / \mathrm{L})$ is similar to that observed by Contador et al. (2015) in the Ro'balo River on sub-Antarctic Navarino Island (8.9-12.6 mg/L).
TABLE 2

Mean \pm standard deviation $(1 \sigma)(\max -\mathrm{min})$ values of $\mathrm{pH}$ and electrical conductivity $(\mathrm{EC}, \mu \mathrm{S} / \mathrm{cm})$ measured by different studies for various streams on the island. See the respective references for methods and equipment used.

\begin{tabular}{|l|c|c|c|}
\hline Reference & $\boldsymbol{N}$ & $\mathrm{pH}$ & $\mathrm{EC}(\mu \mathrm{S} / \mathrm{cm})$ \\
\hline This study & 120 & $7.2 \pm 0.2(1.3)$ & $61.7 \pm 5.6(27.7)$ \\
\hline $\begin{array}{l}\text { Grobbelaar } \\
(1974)\end{array}$ & 26 & $6.8 \pm 0.3(1.2)$ & $62.6 \pm 22.1(120.3)$ \\
\hline $\begin{array}{l}\text { Van Staden } \\
(2011)\end{array}$ & 28 & $6.9 \pm 0.5(1.8)$ & $53.4 \pm 13.5(44.0)$ \\
\hline $\begin{array}{l}\text { Dartnall and } \\
\text { Smith (2012) }\end{array}$ & 19 & $6.8 \pm 0.8(2.4)$ & $66.9 \pm 15.0(59.0)$ \\
\hline
\end{tabular}

Over the time series, there was a sharp, short-term response seen in all stream water physicochemical values (Fig. 2a-d) due to a precipitation event (13 $\mathrm{mm}$ between 15:00 and 21:00 (GMT+3)) associated with a mid-latitude cyclone on 22 April 2015. Following the precipitation event, stream 
$\mathrm{pH}$, water temperature and EC all decreased sharply due to dilution (Fig. 2). In contrast, DO concentrations increased over the same period. A similar pattern for DO was found by Feller and Kimmins (1979) in an undisturbed stream in British Columbia. For $\mathrm{pH}$, a decrease following high rainfall is consistent with studies of streams draining small basins (Caissie et al., 1996). Stream temperature in the SPR decreased by $2.9^{\circ} \mathrm{C}$ following the rainfall event on 22 April 2015 (Fig. 2b). Brown and Hannah (2007) found there to be a significant relationship between total precipitation amount and temperature change, with higher rainfall storms resulting in greater stream water temperature depression. Taken together, these high-frequency data also show that synoptic weather events play a significant role in driving sharp, shortterm changes in stream physicochemistry on sub-Antarctic Marion Island, similar to the effect(s) that synoptic-scale weather systems have on sub-surface soil temperature dynamics on the island (Nel et al., 2009a,b).

\section{Diel cycles}

Diel oscillations in stream water can result from combinations of differing physical, biological, and/or chemical processes that operate on a day-night cycle (Nimick et al., 2011). Changes in stream $\mathrm{pH}$ occur on a daily basis as a result of various processes. Stream $\mathrm{pH}$ generally varies because of changing concentrations of dissolved $\mathrm{CO}_{2}$ caused by aquatic organisms consuming or producing $\mathrm{CO}_{2}$ through photosynthesis and respiration, respectively (Neal et al., 2012). The daily range of stream water $\mathrm{pH}$ values was on average $0.5 \mathrm{pH}$ units (Table 1), which is consistent with the low rates of productivity in streams and limited daylight hours on the island. In the SPR, stream $\mathrm{pH}$ begins to rise after sunrise and increases throughout the day, a pattern that has been observed by other authors (Nimick et al., 2005; Moraetis et al., 2010). In addition, late-afternoon maxima and night-time minima in stream $\mathrm{pH}$ were found in other studies that attributed the $\mathrm{pH}$ cycles to respiration and photosynthesis of aquatic macrophytes and algae (Bäckström et al., 2002; Parker et al., 2007).

Stream water and the air surface are both primarily heated through solar radiation. Their relationship is therefore able to provide insight into physical processes that regulate stream thermal regimes (Drysdale et al., 2003). Air temperature, relative humidity, cloud cover and wind speed all influence the heat exchange between the stream and the atmosphere (Nimick et al., 2011). As a result, sunny cloudless conditions promote larger diel temperature cycles in streams that are not shaded (Fuller and Davis, 1989). Diel stream water temperature dynamics in the SPR mimic the air surface temperature regime cycle, with maxima and minima in the late afternoon and night-time, respectively. This relationship between stream water and air temperature is widely recognised (Gammons et al., 2007). A strong, significant positive relationship existed between SPR stream water temperature and air surface temperature measured at the research station $(r=0.78$, $p<0.0001)$. Stream water temperatures were also on average lower than air surface temperatures and generally lagged behind air surface maxima as a result of the stream's thermal inertia (Lisi et al., 2015).

Stream water temperature is the dominant control on DO concentrations in the SPR. DO concentrations decrease as stream water is warmed and oxygen solubility decreases (Fig. 2b,c; Guasch et al., 1998). This pattern is further supported by the strong, significant negative relationship between DO concentrations and stream water temperature $(r=-0.96, p<0.0001)$, which highlights the temperature dependence of diel DO dynamics (Nimick et al., 2011). Such a relationship is consistent with small, shallow and impoverished streams (Rajwa-Kuligiewicz et al., 2015). The night-time maxima and daytime minima in DO observed in the SPR are also found in oligotrophic mountain streams with steep gradients (Nimick et al., 2011). Similar patterns have been observed elsewhere in streams that have low levels of biological productivity, with the opposite pattern observed in streams with substantial photosynthetic activity (Loperfido et al., 2009).

Diel EC cycles are not as extensively documented as $\mathrm{pH}$, water temperature and DO (Vogt et al., 2010). In the SPR, EC begins to increase in the early afternoon and continues to increase into the night, reaching a maximum concentration between 20:00 and 23:00 GMT+3 (Fig. 2d). Hayashi et al. (2012) observed a similar pattern in the Thur River watershed, north-eastern Switzerland, where EC concentrations increased during the daytime and into the night-time hours. They attributed these EC fluctuations to a combination of biological (photosynthesis), chemical (carbonate equilibrium and precipitation), and physical (groundwater exchange) processes. Elsewhere, diel EC variations have been observed in small streams and attributed to evaporative enrichment during daytime (Calles, 1982), or the result of groundwater discharge, since groundwater typically has higher EC values (Schmidt et al., 2012). However, potential explanations for diel cycles in the SPR will need to be studied further over longer time periods that cover seasonal and inter-annual hydroclimatic variability, in combination with additional data, before this aspect can be satisfactorily resolved.

\section{Limitations and implications}

Although novel, the findings from our study have temporal and spatial limitations. Diel dynamics were investigated over a 7-day period and, therefore, only represent a limited range of annual hydroclimatic and stream chemical variability. Observations of an individual storm, such as that experienced on 22 April 2015, only provides an incomplete illustration of the diversity of hydrochemical behaviours that the SPR catchment can exhibit (Kirchner et al., 2004). Furthermore, SP03 represents a single point in the SPR. Therefore, our results do not account for factors affecting physicochemistry within the catchment such as spatial variability of rainfall, geology, geomorphology, aquatic organisms and differences in physical and chemical characteristics of stream water due to landscape position. Despite the abovementioned constraints, high-frequency monitoring captured the range of previous measurements made manually in numerous streams around the island at various times of the year under differing hydroclimatic conditions (Table 2).

When considering the high-frequency data (Fig. 2), it is clear that there is a wealth of additional information present that has not been previously captured. From the data it is evident that low-resolution sampling (i.e. daily, weekly and/or monthly) will result in the diurnal cycle and the flow response of the catchment not being fully captured. Not only do our data provide context to previous manual measurements, they also show that continuous high-frequency monitoring is necessary to reveal the coupling between hydrological and physicochemical dynamics in the SPR. 


\section{CONCLUSIONS}

Results from this study emphasize the value of continuous high-resolution physicochemical measurements for accurate characterisation of stream chemical dynamics. Through analysis of high-frequency data from the SPR we observed subtle diel cycles throughout the study period, previously undocumented in stream water on the island. Stream $\mathrm{pH}$, superimposed on these oscillations, was a sharp, short-term response in all physicochemical values to a precipitation event, which would otherwise not have been accounted for by lower-resolution sampling. By capturing the full range of daily variation in stream water physicochemistry, these data add valuable context and improved interpretability to discontinuous, manual point-based measurements that have up to now been used to understand stream chemical dynamics on the island. While it is important to note that our results only represent variation at a single location recorded over a limited range of annual climatic variability, these findings are important initial observations that inform on-going monitoring of stream chemical dynamics on sub-Antarctic Marion Island.

\section{ACKNOWLEDGEMENTS}

The research presented here is part of the project Landscape and Climate Interactions in a Changing Sub-Antarctic Environment (grant no. 93075). This research received logistical support from the South African Department of Environmental Affairs. Funding was provided through the National Research Foundation, by the South African Department of Science and Technology under the auspices of the South African National Antarctic Programme. Climate data from the research station on Marion Island was provided by the South African Weather Service.

\section{REFERENCES}

BÄCKSTRÖM M, BÖRJESSON E and KARLSSON S (2002) Diurnal variations of abiotic parameters in a stream, recipient for drainage water in Ranstad, southwest Sweden. J. Environ. Monit. 4 (5) 772-777. https:/doi.org/10.1039/B201659A

BOELHOUWERS J, HOLNESS S and SUMNER P (2003) The maritime Subantarctic: a distinct periglacial environment. Geomorphology 52 (1) 39-55. https://doi.org/10.1016/S0169-555X(02)00247-7

BOELHOUWERS J, MEIKLEJOHN KI, HOLNESS SD and HEDDING DW (2008) Geology, geomorphology and climate change. In: Chown SL and Froneman PW. (eds.) The Prince Edward Islands: Land-sea Interactions in a Changing Ecosystem. Sun Press, Stellenbosch.

BROWN LE and HANNAH DM (2007) Alpine stream temperature response to storm events. J. Hydrometeorol. 8 (4) 952-967. https:// doi.org/10.1175/JHM597.1

BURT TP, HOWDEN NJ, WORRALL F and MCDONNELL JJ (2011) On the value of long-term, low-frequency water quality sampling: avoiding throwing the baby out with the bathwater. Hydrol. Process. 25 (5) 828-830. https://doi.org/10.1002/hyp.7961

CAISSIE D, POLLOCK TL and CUNJAK RA (1996) Variation in stream water chemistry and hydrograph separation in a small drainage basin. J. Hydrol. 178 (1-4) 137-157. https://doi. org/10.1016/0022-1694(95)02806-4

CALLES UM (1982) Diurnal variations in electrical conductivity of water in a small stream. Hydrol. Res. 13 (3) 157-164.

CONTADOR T, KENNEDY JH, ROZZI R and VILLARROEL JO (2015) Sharp altitudinal gradients in Magellanic Sub-Antarctic streams: patterns along a fluvial system in the Cape Horn biosphere reserve (55 S). Polar Biol. 38 (11) 1853-1866. https://doi.org/10.1007/ s00300-015-1746-4

COOPER J, CRAFFORD JE and HECHT T (1992) Introduction and extinction of brown trout (Salmo trutta L.) in an impoverished subantarctic stream. Antarct. Sci. 4 (1) 9-14. https://doi.org/10.1017/ S095410209200004X

DARTNALL HJ and SMITH VR (2012) Freshwater invertebrates of sub-Antarctic Marion Island. Afr. Zool. 47 (2) 203-215. https://doi. org/10.1080/15627020.2012.11407548

DRYSDALE R, LUCAS S AND CARTHEW K (2003) The influence of diurnal temperatures on the hydrochemistry of a tufa-depositing stream. Hydrol. Process. 17 (17) 3421-3441. https://doi.org/10.1002/ hyp. 1301

FELLER MC and KIMMINS JP (1979) Chemical characteristics of small streams near Haney in southwestern British Columbia. Water Resour. Res. 15 (2) 247-258. https://doi.org/10.1029/ WR015i002p00247

FULLER CC and DAVIS JA (1989) Influence of coupling of sorption and photosynthetic processes on trace element cycles in natural waters. Nature 340 (6228) 52-54. https://doi.org/10.1038/340052a0

GAMMONS CH, GRANT TM, NIMICK DA, PARKER SR and DEGRANDPRE MD (2007) Diel changes in water chemistry in an arsenic-rich stream and treatment-pond system. Sci. Total Environ. 384 (1) 433-451. https://doi.org/10.1016/j.scitotenv.2007.06.029

GROBBELAAR JU (1974) A contribution to the limnology of the subAntarctic island Marion. PhD thesis, University of the Orange Free State.

GROBBELAAR JU (1975) The lentic and lotic freshwater types of Marion Island (Sub-Antarctic): a limnological study. Verh. Int. Verein. Limnol. 19 949-951.

GROBBELAAR JU (1978a) The limnology of Marion Island: Southern Indian Ocean. S. Afr. J. Antarct. Res. 8 113-118.

GROBBELAAR JU (1978b) Mechanisms controlling the composition of freshwaters on the sub-Antarctic island Marion. Arch. Hydrobiol. 83 (2) 145-157.

GROBBELAAR JU (1978c) Factors limiting the algal growth on the sub-Antarctic island Marion. Verh. Int. Verein. 20 1159-1164.

GROBBELAAR JU, JARVIS AC, ROBARTS RD, SEPHTON LM, STEENKAMP M and CAWOOD ME (1987) A diel study of carbon flow in the pelagic zone of a small lava-lakelet on Marion Island (sub-Antarctic). Polar Biol. 7 (2) 115-124. https://doi.org/10.1007/ BF00570448

GUASCH H, ARMENGOL J, MARTÍ E and SABATER S (1998) Diurnal variation in dissolved oxygen and carbon dioxide in two low-order streams. Water Res. 32 (4) 1067-1074. https://doi. org/10.1016/S0043-1354(97)00330-8

HALLIDAY SJ, WADE AJ, SKEFFINGTON RA, NEAL C, REYNOLDS B, ROWLAND P, NEAL M and NORRIS D (2012) An analysis of long-term trends, seasonality and short-term dynamics in water quality data from Plynlimon, Wales. Sci. Total Environ. 434 186200. https://doi.org/10.1016/j.scitotenv.2011.10.052

HAYASHI M, VOGT T, MÄCHLER L and SCHIRMER M (2012) Diurnal fluctuations of electrical conductivity in a pre-alpine river: effects of photosynthesis and groundwater exchange. J. Hydrol. 450 93-104. https://doi.org/10.1016/j.jhydrol.2012.05.020

HEDDING DW (2008) Spatial inventory of landforms in the recently exposed central highland of sub-Antarctic Marion Island. S. Afr. Geogr. J. 90 (1) 11-21. https://doi.org/10.1080/03736245.2008.9725307

JORDAN P and CASSIDY R (2011) Technical Note: assessing a $24 / 7$ solution for monitoring water quality loads in small river catchments. Hydrol. Earth Syst. Sci. 15 (10) 3093-3100. https://doi. org/10.5194/hess-15-3093-2011

KIRCHNER JW, FENG X, NEAL C and ROBSON AJ (2004) The fine structure of water-quality dynamics: the (high-frequency) wave of the future. Hydrol. Process. 18 (7) 1353-1359. https://doi. org/10.1002/hyp.5537

LE ROUX PC (2008) Climate and climate change. In: Chown SL and Froneman PW (eds.) The Prince Edward Islands: Land-sea Interactions in a Changing Ecosystem. Sun Press, Stellenbosch. https://doi.org/10.18820/9781928357063/03

LE ROUX PC and MCGEOCH MA (2008) Changes in climate extremes, variability and signature on sub-Antarctic Marion Island. Clim. Change 86 (3-4) 309-329. https://doi.org/10.1007/ s10584-007-9259-y

LISI PJ, SCHINDLER DE, CLINE TJ, SCHEUERELL MD and WALSH PB (2015) Watershed geomorphology and snowmelt control stream thermal sensitivity to air temperature. Geophys. Res. Lett. 42 (9) 
3380-3388. https://doi.org/10.1002/2015GL064083

LOPERFIDO JV, JUST CL and SCHNOOR JL (2009) High frequency diel dissolved oxygen stream data modeled for variable temperature and scale. J. Environ. Eng. 135 (12) 1250-1256. https://doi. org/10.1061/(ASCE)EE.1943-7870.0000102

MCKNIGHT DM, COZZETTO K, CULLIS JD, GOOSEFF MN, JAROS C, KOCH JC, LYONS WB, NEUPAUER R and WLOSTOWSKI A (2015) Potential for real-time understanding of coupled hydrologic and biogeochemical processes in stream ecosystems: future integration of telemetered data with process models for glacial meltwater streams. Water Resour. Res. 51 (8) 6725-6738. https:// doi.org/10.1002/2015WR017618

MORAETIS D, EFSTATHIOU D, STAMATI F, TZORAKI O, NIKOLAIDIS NP, SCHNOOR JL and VOZINAKIS K (2010) High frequency monitoring for the identification of hydrological and biogeochemical processes in a Mediterranean river basin. J. Hydrol. 389 (1) 127-136. https://doi.org/10.1016/j.jhydrol.2010.05.037

NEAL C, REYNOLDS B, ROWLAND P, NORRIS D, KIRCHNER JW, NEAL M, SLEEP D, LAWLOR A, WOODS C, THACKER S and GUYATT H (2012) High frequency water quality time series in precipitation and streamflow: from fragmentary signals to scientific challenge. Sci. Total Environ. 434 3-12. https://doi.org/10.1016/j. scitotenv.2011.10.072

NEL W, BOELHOUWERS JC and ZILINDILE MB (2009a) The effect of synoptic scale weather systems on sub-surface soil temperatures in a diurnal frost environment: preliminary observations from subAntarctic Marion Island. Geogr. Ann. 91 (4) 313-319. https://doi. org/10.1111/j.1468-0459.2009.00372.x

NEL W, VAN DER MERWE B and MEIKLEJOHN KI (2009b) Rethinking climate change impacts on subsurface temperatures in a sub-Antarctic mire affected by synoptic scale processes. Earth Surf. Proc. Land. 34 (10) 1446-1449. https://doi.org/10.1002/ esp. 1823

NIMICK DA, CLEASBY TE and MCCLESKEY RB (2005) Seasonality of diel cycles of dissolved trace-metal concentrations in a Rocky Mountain stream. Environ. Geol. 47 (5) 603-614. https://doi. org/10.1007/s00254-004-1178-x

NIMICK DA, GAMMONS CH and PARKER SR (2011) Diel biogeochemical processes and their effect on the aqueous chemistry of streams: a review. Chem. Geol. 283 (1) 3-17. https://doi. org/10.1016/j.chemgeo.2010.08.017

PARKER SR, GAMMONS CH, POULSON SR and DEGRANDPRE MD (2007) Diel variations in stream chemistry and isotopic composition of dissolved inorganic carbon, upper Clark Fork River, Montana, USA. Appl. Geochem. 22 (7) 1329-1343. https://doi. org/10.1016/j.apgeochem.2007.02.007

PENDLEBURY S and BARNES-KEOGHAN IP (2007) Climate and climate change in the sub-Antarctic. Pap. Proc. R. Soc. Tasmania 141 (1) 67-81.

R DEVELOPMENT CORE TEAM 2016. R: a language and environment for statistical computing. In: R Development Core Team (ed.) R Foundation for Statistical Computing, Vienna, Austria.

RAJWA-KULIGIEWICZ A, BIALIK RJ and ROWIŃSKI PM (2015) Dissolved oxygen and water temperature dynamics in lowland rivers over various timescales. J. Hydrol. Hydromech. 63 (4) $353-$ 363. https://doi.org/10.1515/johh-2015-0041

RAPOSEIRO PM, COSTA AC and HUGHES SJ (2011) Environmental factors-spatial and temporal variation of chironomid communities in oceanic island streams (Azores archipelago). Annal. Limnol. 47 (4) 325-338. https://doi.org/10.1051/limn/2011048

RODE M, WADE AJ, COHEN MJ, HENSLEY RT, BOWES MJ, KIRCHNER JW, ARHONDITSIS GB, JORDAN P, KRONVANG B, HALLIDAY SJ and SKEFFINGTON RA (2016) Sensors in the stream: the high frequency wave of the present. Environ. Sci. Technol. 50 10297-10307. https://doi.org/10.1021/acs.est.6b02155

ROUAULT M, MÉLICE JL, REASON CJ and LUTJEHARMS JR (2005) Climate variability at Marion Island, Southern Ocean, since 1960. J. Geophys. Res. Oceans 110 (C05007). https://doi. org/10.1029/2004JC002492

SCHMIDT C, MUSOLFF A, TRAUTH N, VIEWEG M and FLECKENSTEIN JH (2012) Transient analysis of fluctuations of electrical conductivity as tracer in the stream bed. Hydrol. Earth Syst. Sci. 16 (10) 3689-3697. https://doi.org/10.5194/ hess-16-3689-2012

SCHOLEFIELD D, LE GOFF T, BRAVEN J, EBDON L, LONG T and BUTLER M (2005) Concerted diurnal patterns in riverine nutrient concentrations and physical conditions. Sci. Total Environ. 344 (1) 201-210. https://doi.org/10.1016/j.scitotenv.2005.02.014

SHERSON LR, VAN HORN DJ, GOMEZ-VELEZ JD, CROSSEY LJ and DAHM CN (2015) Nutrient dynamics in an alpine headwater stream: use of continuous water quality sensors to examine responses to wildfire and precipitation events. Hydrol. Process. 29 (14) 3193-3207. https://doi.org/10.1002/hyp.10426

STROBL RO and ROBILLARD PD (2008) Network design for water quality monitoring of surface freshwaters: a review. J. Environ. Manage. 87 (4) 639-648. https://doi.org/10.1016/j. jenvman.2007.03.001

TOMLINSON MS and DE CARLO EH (2003) The need for high resolution time series data to characterise Hawaiian streams. J. Am. Water Resour. Assoc. 39 113-123. https://doi. $\operatorname{org} / 10.1111 / j .1752-1688.2003 . t b 01565 . x$

VAN STADEN W (2011) Limnoecology of the freshwater algal genera (excluding diatoms) on Marion Island (sub-Antarctic). Doctoral thesis, North-West University.

VOGT T, HOEHN E, SCHNEIDER P, FREUND A, SCHIRMER M and CIRPKA OA (2010) Fluctuations of electrical conductivity as a natural tracer for bank filtration in a losing stream. $A d v$. Water Resour. 33 (11) 1296-1308. https://doi.org/10.1016/j. advwatres.2010.02.007

WADE AJ, PALMER-FELGATE EJ, HALLIDAY SJ, SKEFFINGTON RA, LOEWENTHAL M, JARVIE HP, BOWES MJ, GREENWAY GM, HASWELL SJ, BELL IM and co-authors (2012)

Hydrochemical processes in lowland rivers: insights from in situ, high resolution monitoring. Hydrol. Earth Syst. Sci. 16 (11) $4323-$ 4342. https://doi.org/10.5194/hess-16-4323-2012

WILBY RL, JOHNSON MF and TOONE JA (2014) Nocturnal river water temperatures: spatial and temporal variations. Sci. Total Environ. 482 157-173. https://doi.org/10.1016/j. scitotenv.2014.02.123

WLOSTOWSKI AN, GOOSEFF MN, MCKNIGHT DM, JAROS C and LYONS WB (2016) Patterns of hydrologic connectivity in the McMurdo Dry Valleys, Antarctica: a synthesis of 20 years of hydrologic data. Hydrol. Process. 30 (17) 2958-2975. https://doi. org/10.1002/hyp.10818 